\title{
Kamil Giemza
}

\section{Wdrażanie funduszy europejskich w polskim rolnictwie na przykładzie Programu Rozwoju Obszarów Wiejskich na lata 2014-2020}

\begin{abstract}
Streszczenie
Artykuł omawia etapy projektowania i wdrażania funduszy europejskich na przykładzie Programu Rozwoju Obszarów Wiejskich na lata 2014-2020. Przedstawia odpowiedzialne za programowanie środków na rozwój obszarów wiejskich organy i instytucje po stronie Unii Europejskiej, jak i państwa członkowskiego. Wskazuje na najważniejsze wydarzenia i dokumenty niezbędne do uruchomienia pomocy finansowej ze środków Europejskiego Funduszu Rolnego na rzecz Rozwoju Obszarów Wiejskich. Koncentruje się na programowaniu pomocy z EFRROW w postaci PROW, który w Polsce realizowany jest jako jednolity program, wraz z przedstawieniem alokacji środków oraz jej zmian pomiędzy wstępnym a finalnym projektem programu. Analiza wdrażania PROW 2014-2020 uzupełniona jest o obszar zarządzania, w którym podział kompetencji pomiędzy instytucjami i organami państwa jest zróżnicowany. Artykuł wskazuje również na problemy i zaniedbania we wdrażaniu wybranych działań PROW, którego całkowity budżet w perspektywie finansowej 2014-2020 w Polsce wynosi 13,5 mld PLN.
\end{abstract}

Słowa kluczowe: PROW 2014-2020, Program Rozwoju Obszarów Wiejskich, rozwój obszarów wiejskich, Wspólna Polityka Rolna, WPR, perspektywa finansowa 2014-2020 


\title{
Implementation of EU funds in the area of rural development policy presented by the example of the Rural Development Programme for 2014-2020
}

\begin{abstract}
The paper presents the implementation phases of EU funds illustrated by the example of Rural Development Programme for 2014-2020. The author emphasizes the role of authorities and institutions, both the European Union and member states which are responsible for programming EU funds for rural development. The paper indicates the most relevant events and documents necessary to organize financial support from the European Agricultural Fund for Rural Development in Poland. Furthermore, it focuses on the programming of EAFRD assistance in the form of the RDP, which is implemented in Poland in the form of a single programme, together with the presentation of the allocation of funds and their changes between the initial and the final programme. The analysis of the implementation of the RDP 2014-2020 is complemented by a management area in which the division of competencies between institutions is diversified. The article also highlights problems and negligence in the implementation of selected RDP actions, whose total budget in the financial perspective of 2014-2020 in Poland is 13.5 billion zlotys.
\end{abstract}

Keywords: RDP 2014-2020, Rural Development Programme, development of rural areas, Common Agricultural Policy, CAP, financial perspective of 2014-2020

\section{Wspólna Polityka Rolna jako polityka publiczna}

Wspólna Polityka Rolna powstała jako jedna z podstawowych dziedzin polityki Wspólnot Europejskich, funkcjonuje od 1962 r. i opiera się na partnerstwie między sektorem rolnym i społeczeństwem, między Europą a rolnikami. Na początku lat 90. XX w. Wspólna Polityka Rolna (WPR) została rozszerzona o problemy ochrony środowiska, ochrony dziedzictwa krajobrazowego wsi i inne zagadnienia wykraczające poza sprawy stricte rolne. Rolnictwo zyskało zatem nowy, wielofunkcyjny charakter, uwzględniający dostarczanie pewnych dóbr pozaekonomicznych, konsumowanych przez „nierolników”, i uwzględniało paradygmat rozwoju zrównoważonego ${ }^{1}$. Założenie o gotowości społeczeństwa do płacenia za wytwarzanie i ochronę pewnych dóbr publicznych przyjęto niemal na równi z koniecznością utrzymywania wspólnej

1 W. Knieć, Wspólna Polityka Rolna a zrównoważony rozwój obszarów wiejskich Polski. Analiza socjologiczna, Wydawnictwo Naukowe Uniwersytetu Mikołaja Kopernika, Toruń 2012, s. 78. 
infrastruktury drogowej. Kształt i zadania postawione przed szeroko pojętym rolnictwem w Unii Europejskiej odzwierciedla tzw. Europejski Model Rolnictwa ${ }^{2}$.

Biorąc pod uwagę udział w budżecie Unii Europejskiej ${ }^{3}$ oraz liczbę aktów prawnych dotyczących WPR, należy ją uznać za jedną z najważniejszych dziedzin polityki $\mathrm{UE}^{4}$. Po reformie WPR w 2013 r. podkreślono konieczność zachowania dwufilarowej struktury Wspólnej Polityki Rolnej, w ramach której pierwszy filar oparty na horyzontalnym podejściu do rolnictwa w szerszym niż dotąd zakresie uwzględniałby rozwiązania prośrodowiskowe, zaś drugi filar ukierunkowany na osiąganie konkretnych rezultatów w zakresie polityki wiejskiej byłby na tyle elastyczny, by dostosować się do zróżnicowanych warunków krajowych, regionalnych i lokalnych ${ }^{5}$.

Wspólna Polityka Rolna stanowi kompetencję dzieloną ${ }^{6}$ Unii Europejskiej na mocy artykułu 4, ust. 2, lit. d Traktatu o Funkcjonowaniu Unii Europejskiej ${ }^{7}$, jednak jej zakres oddziaływania w bardzo dużym stopniu implikuje prowadzenie polityki rolnej przez państwo. Polityka rolna, zdaniem M. Wigiera, jest jednym z instrumentów polityki publicznej, który w warunkach „zawodności rynku” oraz ograniczonych zasobów służy realizacji celów o charakterze ekonomicznym, społecznym i środowiskowym ${ }^{8}$.

Unia Europejska określa i realizuje Wspólną Politykę Rolną na podstawie art. 38 Traktatu o Funkcjonowaniu Unii Europejskiej (TFUE). Traktatowymi celami WPR są: a) zwiększenie wydajności rolnictwa przez wspieranie postępu technicznego, racjonalny rozwój produkcji rolnej, jak również optymalne wykorzystanie czynników produkcji, zwłaszcza siły roboczej; b) zapewnienie w ten sposób odpowiedniego poziomu życia ludności wiejskiej, zwłaszcza przez podniesienie indywidualnego dochodu osób pracujących w rolnictwie; c) stabilizacja

2 Zob. K. Giemza, Kształtowanie się współczesnego modelu europejskiego rolnictwa a kwestia agrarna, w: Kwestia agrarna. Zagadnienia prawne i ekonomiczne, red. P. Litwiniuk, Fundacja Programów Pomocy dla Rolnictwa FAPA, Warszawa 2016, s. 303-316.

3 Wydatki na Europejski Fundusz Orientacji i Gwarancji Rolnej WPR na przełomie lat 60. i 70. XX w. stanowiły między 80 a 90 proc. wydatków budżetu WE, w latach 80. spadły poniżej 70 proc., a po 2002 r. poniżej 50 proc. W perspektywie finansowej 2014-2020 finansowanie WPR pochłania 40,5 proc. budżetu UE. Por. European Commission, EU Budget 2007 Financial Report, Annex 2: Expenditure 1958-2007 by Heading, Office for Official Publications of the European Communities, Luxembourg 2008, s. 51-57.

4 M. Spychalski, Wpływ Wspólnej Polityki Rolnej Unii Europejskiej na rozwój sektora rolnego i obszarów wiejskich $w$ Polsce - przewidywane korzyści i koszty w pierwszych latach członkostwa, "International Journal of Management and Economics" 2004, Vol. 16, s. 88.

5 E. Tomkiewicz, M. Bocheński, Polityka rozwoju obszarów wiejskich w perspektywie lat 20142020 w kontekście nowych wyzwań, „Studia Iuridica Agraria” 2012, t. X, s. 239.

6 Por. A. Kuś, Rodzaje kompetencji Unii Europejskiej a unijna polityka podatkowa, „Studia z Polityki Publicznej" 2014, nr 2(2), s. 87.

7 Wersja skonsolidowana Traktatu o Funkcjonowaniu Unii Europejskiej, Dz. Urz. UE, C83, 30.03.2010, s. 51 .

8 M. Wigier, Wprowadzenie, w: Analiza efektów realizacji polityki rolnej wobec rolnictwa i obszarów wiejskich, red. M. Wigier, Instytut Ekonomiki Rolnictwa i Gospodarki Żywnościowej - Państwowy Instytut Badawczy, Warszawa 2011, s. 7. 
rynków; d) zagwarantowanie bezpieczeństwa dostaw; e) zapewnienie rozsądnych cen w dostawach dla konsumentów.

Warto zauważyć, że cele, które nie uległy zmianie od czasu Traktatów Rzymskich z marca 1957 r. nie zawierają w sobie odniesień do rozwoju obszarów wiejskich. Kontrowersje budzi jednoczesne występowanie celów zakładających wzrost produkcji i zapewnienie odpowiedniego poziomu życia ludności wiejskiej. Cele te na gruncie racjonalności ekonomicznej stoją ze sobą w sprzeczności, jak zauważa W. Knieć za M. Cardwellem 9 . Potwierdziło to stanowisko Europejskiego Trybunału Sprawiedliwości w wyroku z 13 marca 1968 r. w sprawie W. Beus GmbH \& Co. przeciwko Monachijskiemu Urzędowi Celnemu ${ }^{10}$, w którym stwierdzono, że „cele określone w artykule 39 Traktatu EWG, które mają na celu ochronę rolników i konsumentów nie mogą być wszystkie jednocześnie i w pełni osiągnięte".

Głównym programem pomocowym w ramach WPR w Polsce jest Program Rozwoju Obszarów Wiejskich (PROW). W perspektywie finansowej 2014-2020 finansowany jest w ramach II filara Wspólnej Polityki Rolnej w wysokości 13,5 mld EUR, pochodzących z Europejskiego Funduszu Rolnego na rzecz Rozwoju Obszarów Wiejskich (EFRROW). Stanowi on kontynuację Programu Rozwoju Obszarów Wiejskich na lata 2007-2013 oraz Planu Rozwoju Obszarów Wiejskich z lat 2004-2006. Celem niniejszego artykułu jest przedstawienie programowania i wdrażania Programu Rozwoju Obszarów Wiejskich na lata 2014-2020 w Polsce.

\section{Polityka rozwoju obszarów wiejskich}

Pierwsze mechanizmy WPR zmierzały do poprawy struktur gospodarowania $\mathrm{w}$ rolnictwie, by następnie $\mathrm{w}$ ramach kolejnych reform przechodzić stopniowo do wspierania działań na rzecz poprawy konkurencyjności rolnictwa i leśnictwa oraz poprawy jakości życia na obszarach wiejskich ${ }^{11}$. Istotny zwrot $w$ kierunku finasowania polityki rozwoju obszarów wiejskich został dokonany w 2003 r. wraz z ustanowieniem EFRROW w ramach projektu reformy Wspólnej Polityki Rolnej, czym dano wyraźny sygnał o zwiększaniu roli działań na rzecz wsi, przy jednoczesnej redukcji środków na tzw. I filar, czyli środków służących wspieraniu rolnictwa, np. płatności

9 M. Cardwell, The European Model of Agriculture, Oxford University Press, Oxford 2004, s. 20.

10 European Court Reports, Judgment of the Court of 13 March 1968 - W. Beus GmbH\& Co. v Hauptzollamt München. - Reference for a Preliminary Ruling: Finanzgericht München - Germany. Case 5-67, http:// curia.europa.eu/juris/celex.jsf?celex=61967CJ0005\&lang1=en\&type=TXT\&ancre=, dostęp: 10.09.2017.

11 J. Stoksik, Projektowanie pomocy unijnej w dziedzinie polityki rozwoju obszarów wiejskich, „Studia Iuridica Agraria" 2013, t. XI, s. 100. 
bezpośrednich ${ }^{12}$. Położono nacisk na rozwój obszarów wiejskich poprzez ustanowienie jednego instrumentu finansowania i programowania, tj. wspomnianego wcześniej EFRROW. Oprócz EFFROW w ramach WPR dla potrzeb finansowania środków rynkowych ustanowiony został Europejski Fundusz Rolniczy Gwarancji (EFRG) ${ }^{13}$.

Zarys polityki rozwoju obszarów wiejskich w obecnej perspektywie został określony w dokumentach Komisji Europejskiej w 2010 r. pt. Wspólna polityka rolna do 2020: sprostać wymaganiom przyszłości związanym z żywnością, zasobami naturalnymi i aspektami terytorialnymi oraz Europa 2020. Strategia na rzecz inteligentnego i zrównoważonego rozwoju sprzyjającego włączeniu społecznemu. Nowym rozwiązaniem w obecnej perspektywie jest ściślejsze powiązanie polityki rozwoju obszarów wiejskich z innymi dziedzinami polityki unijnej, z czym wiąże się silniejsza integracja EFRROW z funduszami strukturalnymi, tj. Europejskim Funduszem Rozwoju Regionalnego, Europejskim Funduszem Społecznym, Funduszem Spójności oraz Europejskim Funduszem Morskim i Rybackim.

W obecnym okresie programowania ustanowiono Wspólne Ramy Strategiczne (WRS) stanowiące wspólne założenia prawne dla funduszy strukturalnych, na podstawie których od 2014 r. funkcjonuje także EFRROW. Ustanowienie WRS ma doniosłe skutki w tym sensie, że priorytety polityki rozwoju obszarów wiejskich mogą być wspierane nie tylko przez EFRROW, ale również przez pozostałe fundusze strukturalne, które nadal pod względem organizacyjno-prawnym pozostają odrębne. $\mathrm{Na}$ podstawie wspólnych ram strategicznych zawierane są umowy partnerskie między Komisją Europejską a państwem członkowskim ${ }^{14}$.

Przed uruchomieniem środków finansowych z EFRROW w danym państwie członkowskim niezbędne jest uzgodnienie zasad pomocy Unii Europejskiej. Pierwszym szczegółowym etapem jest programowanie, które zgodnie z definicją ${ }^{15}$ oznacza

12 D. Stankiewicz, Polityka rozwoju rolnictwa $i$ wsi, ,Studia BAS” 2008, nr 12, s. 62.

13 Rozporządzenie 1290/2005 Rady z dnia 21 czerwca 2005 r. w sprawie finansowania wspólnej polityki rolnej, Dz. Urz. UE L 209, 11.08.2005, art. 2.

14 W założeniu umowy o charakterze strategicznym mają służyć większej przejrzystości programów operacyjnych i zmniejszeniu obciążeń biurokratycznych. W świetle proponowanych rozwiązań znaczna część instrumentów polityki wiejskiej mieści się w ramach polityki spójności, co w intencji projektodawcy ma ułatwić koordynację działań. E. Tomkiewicz i M. Bocheński wskazują z drugiej strony na istnienie poważnej obawy zmarginalizowania projektów na rzecz rozwoju obszarów wiejskich i podporządkowania ich polityce spójności: „W praktyce bardzo często ten sam zakres przedmiotowy mają projekty zgłaszane przez potencjalnych beneficjentów z dużych miast i obszarów wiejskich, a kryteria wyboru projektów preferują projekty o większej skali”. Taka sytuacja wydarzyła się w 2007 r., kiedy niewykorzystane środki finansowe na cele polityki rolnej zostały przeznaczone na program Galileo poświęcony stworzeniu systemu nawigacji satelitarnej. E. Tomkiewicz, M. Bocheński, op.cit., s. 242.

15 Rozporządzenie 1305/2013 Parlamentu Europejskiego i Rady z dnia 17 grudnia 2013 r. w sprawie wsparcia rozwoju obszarów wiejskich przez Europejski Fundusz Rolny na rzecz Rozwoju Obszarów Wiejskich (EFRROW) i uchylające rozporządzenie Rady (WE) nr 1698/2005, Dz. Urz. UE L 347, 20.12.2013, art. 2, ust. 1 lit. a. 
kilkuetapowy proces organizacji, podejmowania decyzji i przyznawania zasobów finansowych. Toczy się z udziałem partnerów, ma na celu realizację w perspektywie wieloletniej wspólnego działania przez Unię i państwa członkowskie, zmierzającego do osiągnięcia priorytetów unijnych w zakresie rozwoju obszarów wiejskich.

Wsparcie z EFRROW przez lata ewoluowało - obowiązującym dokumentem programowym nakreślającym strategiczny kontekst programu jest Rozporządzenie Parlamentu Europejskiego i Rady nr 1305/2013 ${ }^{16}$. Artykuł 5 rozporządzenia wskazuje na szczegółowe sześć priorytetów, które stanowią odzwierciedlenie odpowiednich celów tematycznych $\mathrm{WRS}^{17} \mathrm{i}$ zostały przedstawione w sposób ogólny:

1) wspieranie transferu wiedzy i innowacji w rolnictwie, leśnictwie i na obszarach wiejskich;

2) zwiększanie rentowności gospodarstw i konkurencyjności wszystkich rodzajów rolnictwa we wszystkich regionach oraz promowanie innowacyjnych technologii w gospodarstwach i zrównoważonego zarządzania lasami;

3) wspieranie organizacji łańcucha dostaw żywności, w tym przetwarzania i wprowadzania do obrotu produktów rolnych, promowanie dobrostanu zwierząt i zarządzania ryzykiem w rolnictwie;

4) odtwarzanie, ochrona i wzbogacanie ekosystemów powiązanych z rolnictwem i leśnictwem;

5) wspieranie efektywnego gospodarowania zasobami i przechodzenia na gospodarkę niskoemisyjną i odporną na zmianę klimatu w sektorach rolnym, spożywczym i leśnym;

6) wspieranie włączenia społecznego, rozwoju gospodarczego na obszarach wiejskich oraz ograniczania ubóstwa.

Programy realizowane w państwach członkowskich nie muszą być ukierunkowane na wszystkie sześć priorytetów ${ }^{18}$ pod warunkiem uzasadnienia na podstawie analizy „SWOT” oraz ewaluacji ex ante.

EFFROW realizowany jest w państwach członkowskich poprzez program rozwoju obszarów wiejskich, choć art. 6 ust. 2 Rozporządzenia 1305/2013 dopuszcza przedłożenie zbioru programów regionalnych, a nawet programu krajowego i zbioru

16 Ibidem.

17 Wspólne Ramy Strategiczne zgodnie z art. 10 rozporządzenia 1303/2013 ustalają strategiczne zasady kierunkowe dla ułatwienia procesu programowania oraz sektorowej i terytorialnej koordynacji interwencji Unii w ramach EFSI (Europejskie Fundusze Strukturalne i Inwestycyjne) oraz z innymi właściwymi obszarami polityki i instrumentami Unii, zgodnie z celami strategii UE na rzecz inteligentnego, zrównoważonego wzrostu sprzyjającego włączeniu społecznemu, z uwzględnieniem najważniejszych wyzwań terytorialnych dla poszczególnych typów terytoriów.

18 Dopuszczalne jest ukierunkowanie na przynajmniej cztery priorytety (Rozporządzenie 1305/2013, art. 5). 
programów regionalnych. Państwom członkowskim zaproponowano włączenie do swoich programów rozwoju obszarów wiejskich podprogramy tematyczne odnoszące się m.in. do młodych rolników, małych gospodarstw, kobiet na obszarach wiejskich czy krótkich łańcuchów dostaw. W Polsce zdecydowano się kontynuować jednolity na terenie całego państwa PROW.

\section{Projektowanie Programu Rozwoju Obszarów Wiejskich}

Wdrażanie zrównoważonego rozwoju obszarów wiejskich uchodzi za podstawowy cel polityki spójności, a fundusze strukturalne za narzędzia jej realizacji. Za ważny czynnik procesu rozwoju obszarów wiejskich D. Kołodziejczyk uważa system instytucjonalny, obejmujący całokształt wzajemnie powiązanych norm, zasad i organizacji oraz mechanizmów, które przedstawiają wzajemne kontakty uczestników biorących udział w procesie rozwoju obszarów wiejskich ${ }^{19}$.

Projekt PROW w danym państwie członkowskim musi zawierać ewaluację ex ante, analizę SWOT, opis strategii, opis ram wykonania każdego z działań, plany: ewaluacji, finansowy i wskaźników oraz warunki dotyczące wdrażania programów z wyznaczeniem właściwych instytucji. Państwo członkowskie przedkłada całościowy PROW do zatwierdzenia przez Komisję Europejską (KE) w drodze aktu wykonawczego. Rozporządzenie zawiera wykaz działań dotyczących rozwoju obszarów wiejskich, które należało zaprogramować w taki sposób, aby dane działanie faktycznie przyczyniało się do osiągnięcia co najmniej jednego priorytetu unijnego w zakresie rozwoju obszarów wiejskich ${ }^{20}$. Z EFFROW można wykorzy-

19 Znaczenie instytucji w procesie wdrażania zrównoważonego rozwoju rolnictwa i obszarów wiejskich, red. D. Kołodziejczyk, Instytut Uprawy, Nawożenia i Gleboznawstwa - Państwowy Instytut Badawczy, Warszawa 2014, s. 56.

20 Są to działania o szczególnym znaczeniu w kontekście kilku priorytetów Unii: Usługi doradcze, usługi z zakresu zarządzania gospodarstwem i zastępstw; Inwestycje w środki trwałe; Rozwój gospodarstw i działalności gospodarczej; Współpraca; LEADER. Działania o szczególnym znaczeniu dla wspierania transferu wiedzy i innowacji w rolnictwie i leśnictwie oraz na obszarach wiejskich: Transfer wiedzy i działalność informacyjna; Inwestycje w technologie w dziedzinie leśnictwa oraz w przetwarzanie, transport i wprowadzanie do obrotu produktów leśnych. Działania o szczególnym znaczeniu dla poprawy konkurencyjności wszystkich rodzajów gospodarki rolnej i zwiększania rentowności gospodarstw: Systemy jakości produktów rolnych i środków spożywczych. Działania o szczególnym znaczeniu dla poprawy organizacji łańcucha żywnościowego i promowania zarządzania ryzykiem w rolnictwie: Przywracanie potencjału produkcji rolnej zniszczonego w wyniku klęsk żywiołowych i katastrof oraz wprowadzanie odpowiednich środków zapobiegawczych; Zapobieganie zniszczeniom lasów wskutek pożarów lasów, klęsk żywiołowych i katastrof oraz odtwarzanie lasów; Tworzenie grup producentów; Dobrostan zwierzą; Zarządzanie ryzykiem; Ubezpieczenie upraw, zwierząt i roślin; Fundusze wspólnego inwestowania dotyczące chorób zwierząt i roślin i incydentów środowiskowych; Narzędzie stabilizacji dochodów. Działania o szczególnym znaczeniu dla odtwarzania, chronienia i wzmacniania ekosystemów zależnych od rolnictwa 
stać do 0,25 proc. przydziału rocznego na finansowanie europejskiej sieci na rzecz rozwoju obszarów wiejskich $\left(\mathrm{ENRD}^{21}\right)$ oraz europejskie partnerstwo innowacyjne $\left(\mathrm{EIP}^{22}\right)$. Zadaniem sieci jest zbieranie, analizowanie, rozpowszechnianie informacji na temat działalności w dziedzinie rozwoju obszarów wiejskich, rozpowszechnianie dobrych praktyk, dostarczanie informacji oraz zapewnianie wsparcia w zakresie procesów ewaluacji. Z kolei zadaniami EIP są ułatwianie wymiany fachowej wiedzy i ustanawianie dialogu pomiędzy rolnikami a społecznością badawczą. Zadaniem państwa jest utworzenie krajowej sieci obszarów wiejskich (KSOW), która skupia organizacje i struktury administracyjne zaangażowane w rozwój obszarów wiejskich. Całkowita kwota przeznaczona na rozwój obszarów wiejskich od 1 stycznia 2014 r. do 31 grudnia 2020 r. wynosi 84936 mln EUR ${ }^{23}$. Polska otrzymała na lata 2014-2020 łączną kwotę $10941 \mathrm{mln}$ EUR.

Za opracowanie Programu Rozwoju Obszarów Wiejskich odpowiada Ministerstwo Rolnictwa i Rozwoju Wsi, które prowadziło szerokie konsultacje naukowe i społeczne. Umowa na realizację oceny ex-ante została podpisana 26 marca $2013 \mathrm{r}$., tj. od początku organizowania programu, przez co jego przygotowywanie wraz z ewaluacją początkową przebiegało równolegle ${ }^{24}$. Umowa została sfinansowana ze środków Unii Europejskiej w ramach Pomocy Technicznej PROW na lata 2007-2013. Obowiązek przeprowadzenia analizy ex-ante, zgodnie z definicją E. Tomkiewicz i M. Bocheńskiego ${ }^{25}$, oznacza spełnienie ściśle określonych warunków wstępnych związanych z priorytetami polityki rozwoju obszarów wiejskich.

Ewaluatorzy w ramach oceny dokonywali analizy kolejnych wersji programu. Propozycje ewaluatora, dotyczące modyfikacji projektowanych rozwiązań, rozważane były przez Instytucję Zarządzającą (IZ) tj. Ministra Rolnictwa i Rozwoju Wsi i w miarę możliwości uwzględniane w toku bieżącej pracy. Ewaluator uczestniczył w dyskusjach i spotkaniach dotyczących opracowania programu, m.in. w powołanej

\footnotetext{
i leśnictwa oraz wspierania efektywnego gospodarowania zasobami i przechodzenia na gospodarkę niskoemisyjną i odporną na zmianę klimatu w sektorach rolnym, spożywczym i leśnym: Zalesianie i tworzenie terenu zalesionego; Zakładanie systemów rolno-leśnych; Inwestycje zwiększające odporność ekosystemów leśnych i ich wartość dla środowiska; Działania rolno-środowiskowo-klimatyczne; Rolnictwo ekologiczne; Płatności dla obszarów Natura 2000 i płatności związane z ramową dyrektywą wodną; Płatności dla obszarów z ograniczeniami naturalnymi lub innymi szczególnymi ograniczeniami; Usługi leśno-środowiskowo-klimatyczne oraz ochrona lasów. Działania o szczególnym znaczeniu dla wspierania włączenia społecznego, ograniczania ubóstwa i wspierania rozwoju gospodarczego na obszarach wiejskich: Podstawowe usługi i odnowa wsi na obszarach wiejskich oraz LEADER.

${ }^{21}$ European Network for Rural Development.

22 European Innovation Partnership.

23 W tym 0,25 proc. środków finansowych przeznaczonych na pomoc techniczną.

24 Program Rozwoju Obszarów Wiejskich na lata 2014-2020 (PROW 2014-2020), Ministerstwo Rolnictwa i Rozwoju Wsi, Warszawa 2015, s. 9.

25 E. Tomkiewicz, M. Bocheński, op.cit., s. 243.
} 
przez ministra specjalnej grupie roboczej oraz z wykonawcą Strategicznej Oceny Oddziaływania na Środowisko PROW 2014-2020. 17 kwietnia 2013 r. na posiedzeniu Sejmowej Komisji ds. Rolnictwa i Rozwoju Wsi zaprezentowane zostały konsultacje krajowe dotyczące założeń do PROW 2014-2020.

Raport końcowy z oceny ex-ante został ukończony i opublikowany 12 maja 2014 r. $^{26}$. Sporządzono go z punktu widzenia trafności, spójności, skuteczności, efektywności i użyteczności PROW, w odniesieniu do krajowych i unijnych dokumentów strategicznych, takich jak: Krajowy Program Reform, Strategia Rozwoju Kraju do roku 2020, Strategia Zrównoważonego Rozwoju Wsi, Rolnictwa i Rybactwa na lata 2012-2020 oraz Strategia Europa 2020. W analizach odnoszono się do WRS, Umowy Partnerstwa, zaleceń Ministerstwa Rozwoju Regionalnego dotyczących prowadzenia ewaluacji ex-ante programów operacyjnych na lata 2014-2020 oraz wytycznych Komisji Europejskiej. Ocena ex-ante służyła m.in. zdefiniowaniu potrzeb w zakresie rozwoju obszarów wiejskich wynikających z diagnozy aktualnego stanu w sferze społeczno-ekonomicznej, w sektorze rolno-spożywczym w powiązaniu z wynikami w handlu żywnością i spożyciem krajowym, z uwzględnieniem stanu środowiska naturalnego - wypracowanych na podstawie przeprowadzonej analizy SWOT; zapewnieniu spójności wewnętrznej i zewnętrznej programu z punktu widzenia wybranych do wdrażania działań, uwzględnienia różnic regionalnych, presji środowiskowych i uwarunkowań sektorowych oraz przeznaczonych alokacji finansowych i ich zgodności z celami i priorytetami zawartymi w unijnych i krajowych dokumentach strategicznych. Ponadto określała zdolności administracyjne w kontekście systemu instytucjonalnego włączonego w proces wdrażania programu, uwzględniając zarządzanie, monitoring i ewaluację $e^{27}$. Polska 7 kwietnia 2014 r. przedstawiła Komisji Europejskiej propozycję PROW 2014-2020, która została zatwierdzona przez KE 12 grudnia 2014 r. Obecny PROW jest czwartym programem ${ }^{28}$ przeznaczonym na wsparcie wsi i rolnictwa współfinansowanym z UE od czasu akcesji Polski do Unii Europejskiej.

13 marca 2015 r. została opublikowana ustawa z dnia 20 lutego 2015 r. o wspieraniu rozwoju obszarów wiejskich z udziałem środków Europejskiego Funduszu Rolnego na rzecz Rozwoju Obszarów Wiejskich w ramach Programu Rozwoju

26 Ocena ex-ante Programu Rozwoju Obszarów Wiejskich na lata 2014-2020. Raport Końcowy, Instytut Rozwoju Wsi i Rolnictwa Polskiej Akademii Nauk, ECORYS Polska Sp. z o.o. oraz Instytut Uprawy, Nawożenia i Gleboznawstwa - Państwowy Instytut Badawczy, Warszawa 2014.

27 Ibidem, s. 7-8.

28 Poprzednie programy to PROW 2004-2006, SPO Restrukturyzacja i modernizacja sektora żywnościowego oraz rozwój obszarów wiejskich i PROW 2007-2013. 
Obszarów Wiejskich na lata 2014-202029. Dokument zawierający PROW 2014-2020 liczy 727 stron i obejmuje wsparciem 93,1 proc. powierzchni Polski, które stanowią obszary wiejskie zamieszkiwane przez 39,2 proc. ludności (15,1 mln osób).

Warto przyjrzeć się zmianom powstałym od momentu przesłania projektu programu do KE do powstania jego finalnej i zaakceptowanej wersji. A. Mickiewicz i B. Mickiewicz wskazują, że najpoważniejsze zmniejszenie budżetu dotyczyło działania związanego z modernizacją gospodarstw rolnych (o $415 \mathrm{mln}$ EUR) oraz płatności dla obszarów z ograniczeniami (o $164 \mathrm{mln}$ EUR). Z łącznie 579 mln EUR pozyskanych w ten sposób środków dużą część przeznaczono na premie dla młodych rolników (133 mln EUR), restrukturyzację małych gospodarstw (133 mln EUR) oraz działania rolnośrodowiskowe i klimatyczne (124 mln EUR) ${ }^{30}$. Pojawiły się dwa nowe działania, które nie były ujęte w pierwotnym projekcie zgłoszonym $\mathrm{z}$ Polski: Inwestycje w gospodarstwach położonych na obszarach Natura 2000 (61,5 mln EUR) oraz Inwestycje na obszarach OSN ${ }^{31}$ (37,5 mln EUR). Badacze podkreślają, że późne wprowadzenie rozporządzeń i aktów wykonawczych programu przełożyło się na nieprzekazanie beneficjentom w latach 2014-2015 na rozwój obszarów wiejskich 193 mln EUR rocznie ${ }^{32}$. Ten pozorny brak był rekompensowany przez kończenie PROW 2007-2013 według formuły n+2, która oznacza wydłużenie przewidzianego roku zakończenia wsparcia (2013) o dodatkowe dwa lata, tj. do 2015 na realizację przyznanych wcześniej środków finansowych.

Zdaniem E. Kiryluk-Dryjskiej alokacja środków na wybrane działania jest pochodną liczby potencjalnych beneficjentów działań, ukierunkowaną obiektywnym i równym dla wszystkich województw kryterium podziału ${ }^{33}$. Kwoty alokacji na poszczególne działania uzupełniają się w skali kraju i są zasadne. Regiony o korzystniejszej strukturze rolnictwa otrzymują więcej środków z działań Modernizacja gospodarstw rolnych oraz Premia dla młodych rolników. Regiony z mniej korzystną strukturą agrarną zyskują więcej z działań promujących przedsiębiorczość na obszarach wiejskich oraz wspierających rozwój małych gospodarstw. Określenie wysokości wsparcia, choć może ulegać przesunięciom, jest niezwykle istotne z perspektywy programowania, ponieważ niedoszacowanie przyczynia się do spadku zainteresowania beneficjentów,

29 Ustawa z dnia 20 lutego 2015 r. o wspieraniu rozwoju obszarów wiejskich z udziałem środków Europejskiego Funduszu Rolnego na rzecz Rozwoju Obszarów Wiejskich w ramach Programu Rozwoju Obszarów Wiejskich na lata 2014-2020, Dz. U. 2015, poz. 349.

30 A. Mickiewicz, B. Mickiewicz, Charakterystyczne cechy nowego Programu Rozwoju Obszarów Wiejskich na lata 2014-2020, „Roczniki Naukowe Stowarzyszenia Ekonomistów Rolnictwa i Agrobiznesu” 2014, t. XVII, s. 155.

31 Obszary Szczególnego Narażenia.

32 A. Mickiewicz, B. Mickiewicz, op.cit., s. 157.

33 E. Kiryluk-Dryjska, Alokacja środków finansowych na wybrane działania PROW 2014-2020 z wykorzystaniem optymalizacji liniowej, "Journal of Agrobusiness and Rural Development” 2014, nr 3, s. 71. 
a przeszacowanie prowadzi do występowania problemu określanego w literaturze jako rent-seeking problem ${ }^{34}$. PROW 2014-2020 realizowany jest przez 15 działań, 35 poddziałań oraz 42 typy operacji.

\section{Zarządzanie PROW}

Interesującym z perspektywy polityki publicznej zagadnieniem dotyczącym PROW jest zarządzanie nim i podział kompetencji właściwych instytucji i organów państwa. Na gruncie wspomnianej ustawy z 20 lutego 2015 r. zadania związane z realizacją programu zostały przyznane Ministrowi Rolnictwa i Rozwoju Wsi, który pełni funkcję Instytucji Zarządzającej. Minister właściwy do spraw rolnictwa wykonuje zatem zadania państwa członkowskiego w zakresie dotyczącym monitorowania realizacji i ewaluacji programu, powołuje komitet monitorujący oraz przekazuje Komisji Europejskiej roczne sprawozdania ${ }^{35}$. Poszczególne działania i poddziałania zostały podzielone pomiędzy różne wskazane w ustawie instytucje. Instytucją Pośredniczącą (IP) ${ }^{36}$ odpowiadającą za bezpieczny system elektroniczny do rejestrowania, przechowywania i zgłaszania informacji statystycznych na temat programu i jego realizacji jest Agencja Restrukturyzacji i Modernizacji Rolnictwa (ARiMR) ${ }^{37}$. Zadania w zakresie rozwoju lokalnego w ramach inicjatywy LEADER oraz rozwoju lokalnego kierowanego przez społeczność wykonuje samorząd województwa (jako IP) ${ }^{38}$, a za działania „transfer wiedzy i działalność informacyjna” oraz „współpraca” odpowiada Agencja Rynku Rolnego. Dla wyznaczenia obszarów z ograniczeniami naturalnymi lub innych charakteryzujących się szczególnymi ograniczeniami w zakresie wykonywania analiz gleb właściwą instytucją jest Krajowa Stacja Chemiczno-Rolnicza wraz z podlegającymi jej okręgowymi stacjami ${ }^{39}$.

Funkcję akredytowanej agencji płatniczej pełni ARiMR, a w wypadku wybranych działań Agencja Rynku Rolnego i samorząd województwa. Ministerstwo Rolnictwa i Rozwoju Wsi jako IZ sprawuje nadzór nad agencją płatniczą w zakresie wykonywania zadań związanych z przyznawaniem, wypłatą i zwrotem pomocy technicznej; podmiotami wdrażającymi w zakresie wykonywania zadań z przyznawaniem,

\footnotetext{
34 Zob. Znaczenie instytucji..., op.cit., s. 47.

35 Ustawa z dnia 20 lutego 2015 r. o wspieraniu rozwoju..., op.cit., art. 5, ust. 2, pkt 1.

36 Instytucja Zarządzająca programem może przekazywać wykonywanie części swoich zadań do Instytucji Pośredniczących. Pomimo przekazania tych zadań Instytucja Zarządzająca zachowuje całkowitą odpowiedzialność za całość realizacji programu

37 Ustawa z dnia 20 lutego 2015 r. o wspieraniu rozwoju..., op.cit., art. 5, ust. 3.

38 Ibidem, art. 5, ust. 4.

39 Ibidem, art. 6.
} 
wypłatą i zwrotem pomocy. W odniesieniu do instytucji pośredniczących IZ sprawuje nadzór poprzez możliwość żądania przedstawienia informacji i udostępnienia dokumentów, kontroli lub wydawanie wytycznych i poleceń. Warto podkreślić, że na przykładzie poddziałania Wsparcie na wdrażanie operacji w ramach strategii rozwoju lokalnego kierowanego przez społeczność w działaniu M19 pomoc na realizację danej operacji przyznawana jest pod warunkiem uzasadnienia ekonomicznego i wykazania, że operacja nie jest możliwa do realizacji bez udziału środków publicznych. Drugi wymieniony warunek ma za zadanie wyeliminowanie tzw. efektu deadweight, zwanego również efektem biegu jałowego, który wiąże się z oceną efektywności wsparcia publicznego. Innymi słowy, gdy wnioskodawca jest w stanie zrealizować dany projekt, ponieważ posiada odpowiedni kapitał lub ma możliwość pozyskania go, wówczas występuje efekt deadweight, co skutkuje odmową przyznania pomocy.

13 marca 2015 r. Minister Rolnictwa i Rozwoju Wsi powołał Komitet Monitorujący PROW na lata 2014-2020, który wspiera instytucję zarządzającą w procesie monitorowania, wdrażania i zarządzania programem ${ }^{40}$. Zajmuje się m.in. analizowaniem rocznego sprawozdania z realizacji programu i zatwierdza je przed przekazaniem do KE oraz przedstawia zalecenia dotyczące wdrażania programu. W jego skład wchodzi przewodniczący w randze podsekretarza stanu w Ministerstwie Rolnictwa i Rozwoju Wsi, przedstawiciele wybranych resortów ${ }^{41}$, wojewoda wskazany przez Prezesa Rady Ministrów, przedstawiciele m.in. szefów KPRM, ARiMR, ARR, samorządu gminnego, powiatowego i wojewódzkiego, izb rolniczych czy instytutów naukowych - łącznie 49 członków. Członkowie Komitetu wskazują imiennie swoich zastępców. Posiedzenia odbywają się co najmniej raz na rok, a przewodniczący zobowiązany jest przedłożyć ministrowi rolnictwa i rozwoju wsi sprawozdanie za rok poprzedni. Za udział w posiedzeniach nie przysługuje wynagrodzenie. Szczegółowe warunki i tryb przyznawania pomocy finansowej w ramach PROW określa minister rolnictwa i rozwoju wsi w drodze rozporządzeń, które zostały przedstawione w tabeli 1.

Należy zaznaczyć, że rozporządzenia były wydawane nie tylko do działań, ale także do poszczególnych poddziałań realizowanych w ramach przedstawionych w tabeli działań. Przykładowo 3 czerwca 2015 r. minister rolnictwa wydał rozporządzenie dotyczące poddziałania Wsparcie przygotowawcze ${ }^{42}$. Paragraf pierwszy

40 Zarządzenie nr 5 Ministra Rolnictwa i Rozwoju Wsi z dnia 13 marca 2015 r. w sprawie powołania Komitetu Monitorującego Program Rozwoju Obszarów Wiejskich na lata 2014-2020, §3.

41 Przedstawiciele resortów rozwoju wsi, finansów publicznych, rozwoju regionalnego, środowiska, pracy, nauki i gospodarki.

42 Rozporządzenie Ministra Rolnictwa i Rozwoju Wsi z dnia 3 czerwca 2015 r. w sprawie szczegółowych warunków i trybu przyznawania pomocy finansowej w ramach poddziałania Wsparcie przygotowawcze, objętego Programem Rozwoju Obszarów Wiejskich na lata 2014-2020, Dz. U. 2015, poz. 851. 
rzeczonego rozporządzenia precyzuje, że wspomniane poddziałanie stanowi część działania Wsparcie dla rozwoju lokalnego w ramach inicjatywy LEADER, oznaczonego kodem M19 zgodnie z opisem działań PROW 2014-202043. Innymi słowy, na podstawie uruchomienia jednego poddziałania dane działanie zostało uznane jako uruchomione w tabeli. Dane w tabeli wskazują na dosyć rozłożone w czasie wdrażanie poszczególnych instrumentów wsparcia PROW, z których dziewięć zostało uruchomionych w roku 2015, cztery w 2016, a dwa w 2017. Choć do 2015 roku kończono wsparcie z PROW 2007-2013, to jednak z perspektywy zarządzania i przejrzystości polityki publicznej wskazane byłoby przedstawienie warunków wsparcia i przyznawania pomocy z nowego programu odpowiednio wcześniej. Zważywszy na fakt, że terminy naborów ogłaszane są przez prezesa ARiMR (niezależnie od wydanego rozporządzenia), to zapoznanie potencjalnych beneficjentów z zasadami wsparcia powinno być dokonywane z wyraźnym wyprzedzeniem.

\section{Tabela 1. Uruchomienie działań z PROW 2014-2020}

\begin{tabular}{|c|c|c|}
\hline Kod & Działanie & Data rozporządzenia \\
\hline M01 & Transfer wiedzy i działalność informacyjna & 21 kwietnia $2017 \mathrm{r}$. \\
\hline M02 & $\begin{array}{l}\text { Usługi doradcze, usługi z zakresu zarządzania gospodarstwem i usługi z zakresu } \\
\text { zastępstw }\end{array}$ & 21 marca $2017 \mathrm{r}$. \\
\hline M03 & Systemy jakości produktów rolnych i środków spożywczych & 6 sierpnia $2015 \mathrm{r}$. \\
\hline M04 & Inwestycje w środki trwałe & 21 sierpnia $2015 \mathrm{r}$. \\
\hline M05 & $\begin{array}{l}\text { Przywracanie potencjału produkcji rolnej zniszczonego w wyniku klęsk żywiołowych } \\
\text { i katastrof oraz wprowadzanie odpowiednich środków zapobiegawczych }\end{array}$ & 4 listopada $2016 \mathrm{r}$. \\
\hline M06 & Rozwój gospodarstw i działalności gospodarczej & 13 lipca 2015 r. \\
\hline M07 & Podstawowe usługi i odnowa wsi na obszarach wiejskich & 4 września $2015 \mathrm{r}$. \\
\hline M08 & Inwestycje w rozwój obszarów leśnych i poprawę żywotności lasów & 8 maja 2015 r. \\
\hline M09 & Tworzenie grup i organizacji producentów & 2 sierpnia $2016 r$. \\
\hline M10 & Działanie rolno-środowiskowo-klimatyczne & 18 marca 2015 r. \\
\hline M11 & Rolnictwo ekologiczne & 13 marca 2015 r. \\
\hline M13 & $\begin{array}{l}\text { Płatności dla obszarów z ograniczeniami naturalnymi lub innymi szczególnymi } \\
\text { ograniczeniami }\end{array}$ & 13 marca $2015 \mathrm{r}$. \\
\hline M16 & Współpraca & 23 grudnia $2016 \mathrm{r}$. \\
\hline M19 & $\begin{array}{l}\text { Wsparcie dla rozwoju lokalnego w ramach inicjatywy LEADER (RLKS - rozwój } \\
\text { lokalny kierowany przez społeczność) }\end{array}$ & 3 czerwca 2015 r. \\
\hline M20 & Pomoc techniczna z inicjatywy państw członkowskich & 25 lutego $2016 \mathrm{r}$. \\
\hline
\end{tabular}

Źródło: opracowanie własne na podstawie Rozporządzeń Ministra Rolnictwa i Rozwoju Wsi dotyczących warunków i trybu przyznawania pomocy w ramach poszczególnych instrumentów wsparcia PROW 2014-2020.

43 Por. Program Rozwoju..., op.cit., s. 235. 
Pomimo długiego procesu konsultacyjnego i funkcjonującego systemu doradztwa rolniczego podczas realizowania PROW dochodzi do dysfunkcji, takich jak w poddziałaniu Inwestycje w gospodarstwach położonych na obszarach OSN w ramach działania Inwestycje w środki trwałe, które stanowiło treść rozporządzenia z 4 listopada $2015 \mathrm{r}^{44}$. Nabór został uruchomiony 10 lutego $2016 \mathrm{r}$. i w województwie mazowieckim Regionalny Zarząd Gospodarki Wodnej w Warszawie zakwalifikował ponad 270 ha ziemi jako szczególnie narażone na zanieczyszczenia związkami azotu pochodzenia rolniczego ${ }^{45}$. Informacja ta nie dotarła do potencjalnych beneficjentów, którzy byli zaskoczeni, że gospodarują we wspomnianej strefie OSN. Innymi słowy, rolnicy nie wiedzieli, że mogą się starać o pomoc w ramach dedykowanego im poddziałania. Brak komunikacji i wydania rozporządzenia z odpowiednim wyprzedzeniem doprowadził do poważnego ograniczenia funkcjonowania wspomnianej pomocy i przyczynił się do protestów mazowieckiego samorządu rolniczego.

Odpowiedzialność za część działań została przekazana jako zadania delegowane samorządom wojewódzkim ${ }^{46}$ czy Agencji Rynku Rolnego (ARR). Warto w tym miejscu wskazać na możliwe zakłócenia w realizowaniu funduszy przyznanych w ramach PROW ze względu na niedawną likwidację ARR i nowo utworzony Krajowy Ośrodek Wsparcia Rolnictwa (KOWR). ARR dotychczas odpowiadała za działania Systemy jakości produktów rolnych i środków spożywczych oraz Współpraca $^{47}$. Ich wykonywanie zostało przejęte przez KOWR ${ }^{48}$. Ustawa weszła w życie z dniem 1 września 2017 r., stąd nie sposób dokonać choć wstępnej analizy skutków wprowadzonej zmiany.

\section{$* * *$}

Pomimo kilkuetapowych konsultacji społecznych nad PROW 2014-2020 rozpoczętych w kwietniu 2013 r. nie udało się zapobiec zaniedbaniom w postaci braku poinformowania beneficjentów czy też opóźnieniom we wdrażaniu poszczególnych działań. Mogłoby się wydawać, że przez ponad dekadę funkcjonowania WPR w Polsce

44 Rozporządzenie Ministra Rolnictwa i Rozwoju Wsi z dnia 23 października 2015 r. w sprawie szczegółowych warunków i trybu przyznawania oraz wypłaty pomocy finansowej na operacje typu Inwestycje w gospodarstwach położonych na obszarach OSN, w ramach poddziałania Wsparcie inwestycji w gospodarstwach rolnych, objętego Programem Rozwoju Obszarów Wiejskich na lata 2014-2020, Dz. U. 2015, poz. 1795.

45 Rolnicy nie wiedza, że gospodarują na OSN, http://www.agronews.com.pl/pl/12,55,19824,0,1, rolnicy_nie_wiedza_ze_gospodaruja_na_osn.html, dostęp: 11.09.2017.

46 Zob. P. Litwiniuk, Pozycja samorządu województwa w zakresie wdrażania działań objętych Programem Rozwoju Obszarów Wiejskich, w: red. P. Litwiniuk, Samorzad terytorialny w procesie rozwoju gospodarczego obszarów wiejskich, Instytut Prawa Ustrojowego, Warszawa 2015, s. 337-345.

47 Ustawa z dnia 20 lutego 2015 r. o wspieraniu rozwoju..., op.cit., art. 6, ust. 3, pkt 2.

48 Ustawa z dnia 10 lutego 2017 r. o Krajowym Ośrodku Wsparcia Rolnictwa, Dz. U. 2017, poz. 623, art. 39 . 
beneficjenci i administracja wypracowali mechanizmy niezbędne do prawidłowego wdrażania programów pomocowych. Przypomnę, że środki pomocowe były realizowane na długo przed akcesją Polski do UE. W obszarze rolnictwa już od początku lat 90. XX w. realizowano program PHARE ${ }^{49}$, a przełomowy, bo pełniący zdaniem W. Kniecia funkcję „efektu demonstracyjnego" ${ }^{50}$, program SAPARD realizowany był po 2000 roku.

Przedstawione wybrane aspekty programowania środków pomocowych składają się na proces skomplikowany, angażujący nie tylko przedstawicieli danego sektora gospodarki, ale i wiele powiązanych podmiotów. Programowanie wymaga współpracy licznych instytucji, ośrodków analitycznych, naukowych, jak i potencjalnych beneficjentów. PROW 2014-2020 realizuje cel ogólny oraz cele szczegółowe odpowiadające misji i celom WPR, a także priorytetom rozwoju obszarów wiejskich Unii Europejskiej. Celem ogólnym jest poprawa konkurencyjności rolnictwa, zrównoważone zarządzanie zasobami naturalnymi, działania w dziedzinie klimatu, a także zrównoważony rozwój terytorialny obszarów wiejskich. Zdaniem byłego ministra rolnictwa Marka Sawickiego, „najważniejszą sprawą było skonstruowanie nowego PROW tak, by wzmocnić współpracę między rolnikami, a także między przetwórcami, czyli pomóc w utworzeniu poziomych i pionowych powiązań. Ma uwzględniać w większym stopniu potrzeby konsumentów, stąd wiele środków zostało przeznaczonych na umocnienie małych i średnich gospodarstw, które produkują żywność o podwyższonej jakości. Celem, który resort rolnictwa chciałby osiągnąć w 2020 roku była większa liczba gospodarstw rodzinnych (do 300 ha), samodzielnych ekonomicznie, produkujących bardziej pod potrzeby konsumentów, lepiej zorganizowanych, współuczestniczących w kształtowaniu rynku rolnego i nie oczekujących na kolejne wsparcie od ministra rolnictwa”"51. Do 31 lipca 2017 r. do PROW 2014-2020 złożono 2621943 wniosków na 25,4 mld PLN (43,94 proc. limitu), z których zawarto 1696748 umów (30,55 proc. limitu) i wypłacono 7,5 mld PLN $(12,73 \text { proc. limitu })^{52}$.

49 Poland and Hungary: Assistance for Restructuring their Economies.

50 W. Knieć, op.cit., s. 116-117.

51 Sawicki: PROW na lata 2014-2020 - bardziej ukierunkowany na konsumenta, http://wyborcza. pl/1,91446,17152328, Sawicki_PROW_na_lata_2014_2020__bardziej_ukierunkowany.html, dostęp: 10.09.2017.

52 Sprawozdanie miesięczne z realizacji Programu Rozwoju Obszarów Wiejskich na lata 2014-2020 od uruchomienia Programu na dzień 31.07.2017r., http://www.minrol.gov.pl/Wsparcie-rolnictwa/Program-Rozwoju-Obszarow-Wiejskich-2014-2020/Monitoring-i-sprawozdawczosc-PROW-2014-2020/ Sprawozdania-miesieczne-z-realizacji-PROW-2014-2020/Sprawozdanie-miesieczne-z-realizacji-PROW-na-lata-2014-202019, dostęp: 11.09.2017. 


\section{Bibliografia}

Cardwell M., The European Model of Agriculture, Oxford University Press, Oxford 2004.

European Commission, EU Budget 2007 Financial Report, Annex 2: Expenditure 1958-2007 by heading, Office for Official Publications of the European Communities, Luxembourg 2008.

European Court Reports, Judgment of the Court of 13 March 1968 - W. Beus GmbH \& Co. v Hauptzollamt München. - Reference for a preliminary ruling: Finanzgericht München

- Germany. Case 5-67, http://curia.europa.eu/juris/celex.jsf?celex=61967CJ0005\&lang $1=$ en\&type $=$ TXT\&ancre $=$

Giemza K., Kształtowanie się współczesnego modelu europejskiego rolnictwa a kwestia agrarna, w: Kwestia agrarna. Zagadnienia prawne i ekonomiczne, red. P. Litwiniuk, Fundacja Programów Pomocy dla Rolnictwa FAPA, Warszawa 2016.

http://www.agronews.com.pl/pl/12,55,19824,0,1,rolnicy_nie_wiedza_ze_gospodaruja_na_osn. html

Kiryluk-Dryjska E., Alokacja środków finansowych na wybrane działania PROW 2014-2020 $z$ wykorzystaniem optymalizacji liniowej, "Journal of Agrobusiness and Rural Development" 2014, nr 3.

Knieć W., Wspólna Polityka Rolna a zrównoważony rozwój obszarów wiejskich Polski. Analiza socjologiczna, Wydawnictwo Naukowe Uniwersytetu Mikołaja Kopernika, Torun 2012.

Kuś A., Rodzaje kompetencji Unii Europejskiej a unijna polityka podatkowa, „Studia z Polityki Publicznej” 2014, nr 2(2).

Litwiniuk P., Pozycja samorządu województwa w zakresie wdrażania działań objętych Programem Rozwoju Obszarów Wiejskich, w: Samorzad terytorialny w procesie rozwoju gospodarczego obszarów wiejskich, red. P. Litwiniuk, Instytut Prawa Ustrojowego, Warszawa 2015.

Mickiewicz A., Mickiewicz B., Charakterystyczne cechy nowego Programu Rozwoju Obszarów Wiejskich na lata 2014-2020, „Roczniki Naukowe Stowarzyszenia Ekonomistów Rolnictwa i Agrobiznesu” 2014, t. XVII.

Ocena ex-ante Programu Rozwoju Obszarów Wiejskich na lata 2014-2020. Raport końcowy, Instytut Rozwoju Wsi i Rolnictwa Polskiej Akademii Nauk, ECORYS Polska Sp. z o.o. oraz Instytut Uprawy, Nawożenia i Gleboznawstwa - Państwowy Instytut Badawczy, Warszawa 2014.

Program Rozwoju Obszarów Wiejskich na lata 2014-2020 (PROW 2014-2020), Ministerstwo Rolnictwa i Rozwoju Wsi, Warszawa 2015.

Rozporządzenie 1290/2005 Rady z dnia 21 czerwca 2005 r. w sprawie finansowania wspólnej polityki rolnej, Dz. Urz. UE L 209, 11.08.2005.

Rozporządzenie 1305/2013 Parlamentu Europejskiego i Rady z dnia 17 grudnia 2013 r. w sprawie wsparcia rozwoju obszarów wiejskich przez Europejski Fundusz Rolny na rzecz Rozwoju Obszarów Wiejskich (EFRROW) i uchylające rozporządzenie Rady (WE) nr 1698/2005, Dz. Urz. UE L 347, 20.12.2013. 
Rozporządzenie Ministra Rolnictwa i Rozwoju Wsi z dnia 23 października 2015 r. w sprawie szczegółowych warunków i trybu przyznawania oraz wypłaty pomocy finansowej na operacje typu Inwestycje w gospodarstwach położonych na obszarach OSN, w ramach poddziałania Wsparcie inwestycji w gospodarstwach rolnych, objętego Programem Rozwoju Obszarów Wiejskich na lata 2014-2020, Dz. U. 2015, poz. 1795.

Rozporządzenie Ministra Rolnictwa i Rozwoju Wsi z dnia 3 czerwca 2015 r. w sprawie szczegółowych warunków i trybu przyznawania pomocy finansowej w ramach poddziałania Wsparcie przygotowawcze, objętego Programem Rozwoju Obszarów Wiejskich na lata 2014-2020, Dz. U. 2015, poz. 851.

Spychalski M., Wpływ Wspólnej Polityki Rolnej Unii Europejskiej na rozwój sektora rolnego i obszarów wiejskich w Polsce - przewidywane korzyści i koszty w pierwszych latach członkostwa, "International Journal of Management and Economics" 2004, t. 16.

Stankiewicz D., Polityka rozwoju rolnictwa i wsi, „Studia BAS” 2008, nr 12.

Stoksik J., Projektowanie pomocy unijnej $w$ dziedzinie polityki rozwoju obszarów wiejskich, „Studia Iuridica Agraria” 2013, t. XI.

Tomkiewicz E., Bocheński M., Polityka rozwoju obszarów wiejskich w perspektywie lat 20142020 w kontekście nowych wyzwań, „Studia Iuridica Agraria”, 2012, t. X.

Ustawa z dnia 10 lutego 2017 r. o Krajowym Ośrodku Wsparcia Rolnictwa, Dz. U. 2017, poz. 623 , art. 39.

Ustawa z dnia 20 lutego 2015 r. o wspieraniu rozwoju obszarów wiejskich z udziałem środków Europejskiego Funduszu Rolnego na rzecz Rozwoju Obszarów Wiejskich w ramach Programu Rozwoju Obszarów Wiejskich na lata 2014-2020, Dz. U. 2015, poz. 349.

Wersja skonsolidowana Traktatu o Funkcjonowaniu Unii Europejskiej, Dz. Urz. UE, C83, 30.03.2010.

Wigier M., Wprowadzenie, w: Analiza efektów realizacji polityki rolnej wobec rolnictwa i obszarów wiejskich, red. M. Wigier, Instytut Ekonomiki Rolnictwa i Gospodarki Żywnościowej - Państwowy Instytut Badawczy, Warszawa 2011.

Zarządzenie nr 5 Ministra Rolnictwa i Rozwoju Wsi z dnia 13 marca 2015 r. w sprawie powołania Komitetu Monitorującego Program Rozwoju Obszarów Wiejskich na lata 2014-2020.

Znaczenie instytucji w procesie wdrażania zrównoważonego rozwoju rolnictwa i obszarów wiejskich, red. D. Kołodziejczyk, Instytut Uprawy, Nawożenia i Gleboznawstwa - Państwowy Instytut Badawczy, Warszawa 2014. 
